УДК 656

Т.В. Бслікова, Х.Р. Юричко, канд. техн. наук А.Л. Обухова

\title{
ВПЛИВ ПАРАМЕТРІВ ІНФРАСТРУКТУРИ ЗАЛІЗНИЧНОГО ТРАНСПОРТУ НА ПЛАН ФОРМУВАННЯ ПОЇЗДІВ
}

Представив д-р техн. наук, професор А.М. Котенко

Вступ та аналіз попередніх досліджень. Залізничний транспорт $\epsilon$ найбільш надійним і ефективним видом транспорту, він займає особливе місце в економіці нашої держави. На частку залізниць, якщо не брати до уваги трубопровідний транспорт, припадає більше вісімдесяти відсотків вітчизняного вантажообігу.
Маршрутизація перевезень, що виникла в 20-30-х роках минулого сторіччя, поступово переросла в сучасну теорію організації вагонопотоків. Розвиток теорії супроводжувався появою методів розрахунку плану формування поїздів (ПФП) [5].

Однією 3 основних проблем при розрахунку ПФП є облік рівня розвитку 
інфраструктури залізничного транспорту пропускної спроможності дільниць та переробної спроможності станцій.

Основи теорії та практики розрахунку ПФП заклали професори I.I. Васильєв, К.А. Бернгард, А.К. Угрюмов, В.М. Акулінічев та ін. [1,3,5]. На основі їх методів були розроблені перші методики розрахунку ПФП з використанням ЕОМ, що стало значним поштовхом до вдосконалення як самих методів, так i теорії організації вагонопотоків.

На сьогодні сучасна теорія розрахунку ПФП не в повній мірі враховує сучасні умови поділу власників рухомого складу та новітні технології автоматизації розрахунку ПФП на основі інших діючих на залізничному транспорті автоматизованих систем.

Виклад основного матеріалу. Реальна експлуатаційна ситуація істотно відрізняється від нормативних умов, а труднощі, які виникають при цьому, нерідко поглиблюються неоптимально прийнятими рішеннями. Технологічні документи самі по собі ще не гарантують реалізації своїх можливостей [2].

Для складання ПФП користуються середньодобовими розмірами вагонопотоків. Однак фактичні середньодобові значення багатьох вагонопотоків за місяць, квартал і рік суттєво відрізняються один від одного. Відхилення фактичних розмірів вагонопотоків від розрахункових іноді становлять $\quad 40-60 \%$. При будь-якому відхиленні фактичного середньодобового вагонопотоку від розрахункового прийнятий варіант ПФП вже не можна вважати оптимальним, оскільки закладені в нього норми тим чи іншим чином враховують розміри вагонопотоків. Крім того, при значних відхиленнях розмірів вагонопотоків прийнятий ПФП не тільки не забезпечує економічної ефективності просування вагонопотоку, але і створює значні труднощі в експлуатаційній роботі станцій i дільниць, a іноді i повну неможливість виконання прийнятого варіанта плану формування в поточній оперативній обстановці на мережі залізниць. Тому одним з основних завдань при складанні мережевого ПФП $\epsilon$ правильний розподіл сортувальної роботи між станціями відповідно до їх технічної потужності [3].

Для забезпечення виконання ПФП виконується перевірка:

1) відповідності числа сортувальних колій на кожній станції числу призначень поїздів за ПФП;

2) відповідності переробної спроможності гірок та витяжок 3 урахуванням резерву числа поїздів і вагонів, що надходять у переробку на дану станцію за ПФП.

Для розрахунку ПФП користуються обмеженим набором станцій. Станції, що входять у цей набір, називають розрахунковими, а полігон, який формується цими станціями на мережі залізниці, називають розрахунковим полігоном [3, 4, 5]. Так як ПФП встановлює порядок формування i розформування поїздів на станціях, то головна увага при розрахунку ПФП приділяється сортувальним станціям.

Пропускна спроможність станції визначається найбільш імовірним числом вантажних поїздів (окремо без переробки і 3 переробкою) i заданим числом пасажирських поїздів, які можуть бути пропущені станцією за добу по всіх прилеглих до неї напрямах.

Переробна спроможність станції визначається числом вантажних поїздів (вагонів), які можуть бути перероблені станцією за добу при передовій технології і найкращому використанні колійного розвитку і технічного оснащення.

Розрахунок пропускної та переробної спроможності виконується на основі таких даних [4]:

- схеми і технічно розпорядчого акта станції;

- технічних норм i технологічного процесу роботи станції; 
- технічного оснащення станції та прилеглих до неї дільниць ; pyxy;

- вихідних для розрахунку розмірів станції.

- специфіки роботи і місцевих умов

Таким чином, розвиток автоматизованих систем, які включали б у себе весь комплекс необхідної інформації для проведення розрахунків щодо пропускної спроможності і переробній спроможності станцій i дільниць або містили готову вихідну інформацію 3 результатами розрахунків, дозволить у майбутньому автоматизовано вибирати необхідні дані про роботу інфраструктури для розрахунку ПФП. Для використання інформації про технічний розвиток станції при розрахунку ПФП необхідно всі величини, що відображають рівень розвитку, привести до загальної одиниці виміру. Як таку одиницю виміру зручно використовувати кількість вагонів, які станція може пропустити i переробити. Зручність в розрахунках можна обгрунтувати тим, що при розрахунку ПФП маємо справу 3 вагонокореспонденціями, які вимірюються у вагонах. Інформація про поїзди з'являється після розрахунку ПФП і складання графіка руху з ув'язкою поїзних локомотивів, але використовується для остаточної перевірки здійсненності отриманого варіанта ПФП.
Залізничні лінії з'єднують станції в єдину залізничну мережу. По лініях здійснюється перевезення вагонів між станціями у складі поїздів, сформованих відповідно до ПФП.

Головною характеристикою лінії $є$ iï пропускна спроможність, обумовлена розмірами перевезень, які вона може освоїти (пропустити) протягом певного періоду часу. Пропускна спроможність залізничної лінії залежить від технічної оснащеності лінії, типу прийнятого графіка руху поїздів, технології роботи станцій та iн.

\section{Висновок та перспективи} подальших досліджень. Існуючі методики розрахунку ПФП вказують на те, що питання обліку технічної оснащеності станцій і дільниць завжди відходить на другий план i не є одним з критеріїв. План необхідно піддавати коректуванню вже після розрахунку, в результаті чого кінцевий варіант може втратити свою перевагу перед іншими варіантами організації вагонопотоків i вже не $\epsilon$ оптимальним. Таким чином, необхідно активно розвивати автоматизовані системи на залізничному транспорті, що дасть можливість створити умови для врахування технічного розвитку станцій і дільниць при автоматизованому розрахунку плану формування поїздів.

\section{Список літератури}

1. Бернгард, К.А. Техническая маршрутизация железнодорожных перевозок [Текст] / К.А. Бернгард. - М.: Трансжелдориздат, 1956. - 237 с.

2. Левин, Д.Ю. Оптимизация потоков поездов [Текст] / Д.Ю. Левин. - М.: Транспорт, 1988. $-175 \mathrm{c}$.

3. Повороженко, Эксплуатация железных дорог / В.В. Повороженко, В.М. Акулиничев [и др.]. - М.: Транспорт, 1974. - 472 с.

4. Раев, П.В. Модифицированный метод абсолютного расчета плана формирования поездов для разветвленных направлений: Актуальные проблемы управления перевозочным процессом [Текст] / П.В. Раев. - СПб.: ПГУПС, 2006. - Вып. 6. - С. 129-141.

5. Угрюмов, А.К. Совершенствование методов расчета плана формирования [Текст] / А.К. Угрюмов // Ж.-д. транспорт. - 1953. - № 6. 
Ключові слова: інфраструктура залізничного транспорту, план формування поїздів, переробна спроможність, експлуатаційна робота дільниць.

\section{Анотаціï}

На основі аналізу існуючих методик розрахунку плану формування поїздів зроблено висновок, що необхідно активно розвивати автоматизовані системи на залізничному транспорті, що дають можливість створити умови для врахування технічного розвитку станцій і дільниць при автоматизованому розрахунку плану формування поїздів.

На основе анализа существующих методов расчета плана формирования поездов сделан вывод о необходимости активно развивать автоматизированные системы на железнодорожном транспорте, которые дают возможность создать условия для учета технического развития станций и участков при автоматизированном расчете плана формирования поездов.

On the basis of analysis of existent methods of calculation of plan of forming of trains a conclusion is done, that it is necessary actively to develop CASS on a railway transport, which enable to create terms for the account of technical development of the stations and areas at the automated calculation of plan of forming of trains. 